\title{
Geotechnical Terrain Models and Types of Instabilities in the Durmitor Flysch Complex
}

\section{Geotehnični Terenski Modeli in Vrste Nestabilnosti v Durmitorskem Flišnem Kompleksu}

\author{
Aleksandar Golijanin ${ }^{1,}{ }^{,}$, Vladimir Malbašić ${ }^{2}$ \\ ${ }^{1}$ Market Surveillance Agency of $\mathrm{BiH}$, Karađorđeva 8, Sarajevo, Bosnia and Herzegovina \\ ${ }^{2}$ Faculty of Mining, Prijedor, University of Banja Luka, Street of Savo Kovačević, Bosnia and Herzegovina \\ *aleksandar.golijanin@annt.gov.ba
}

\begin{abstract}
The Durmitor flysch complex represents a specific formation both in lithological and engineering geological sense. In the engineering geological sense this lithological formation is characterized by anisotropic and heterogeneous geotechnical properties, which depend on the dominant members within each individual package, as well as their spatial position.The Durmitor flysch complex consists of five superposition bed packages, which are mutually substantially different in their lithological, hydrogeological and geotechnical properties. For the first time in geological literature, this paper distinguishes five types of terrain construction within the Durmitor flysch complex. Contemporary geodynamic processes and their character within the flysch formation are defined. Particular emphasis is put on landslides, which represent a contemporary geodynamic phenomenon with certain specificities.
\end{abstract}

Key words: durmitor flysch complex, geotechnical models

\section{Povzetek}

Durmitorski flišni kompleks predstavlja posebno formacijo v litološkem in tudi inženirsko-geološkem smislu. V inženirsko-geološkem smislu so značilne zanjo anizotropne in heterogene geotehnične lastnosti, ki so odvisne od prevladujočih členov v vsakem posameznem paketu in prav tako od njihove prostorske lege. Durmitorski flišni kompleks sestoji iz petih drug na drugega naloženih paketov plasti, ki se medsebojno bistveno razlikujejo v litoloških, hidrogeoloških in geotehnični lastnostih. Prvič v geološki literaturi ta članek obravnava pet tipov terenske gradnje v durmitorskem flišnem kompleksu. Opredeljuje sodobne geodinamične procese $v$ flišni formaciji in njihove posebnosti. Posebno pozornost posveča plazovom, ki predstavljajo sodobni geodinamski pojav z nekaterimi posebnimi lastnostmi.

Ključne besede: durmitorski flišni kompleks, geotehnični modeli 


\section{Introduction}

This paper presents the categorization of terrain construction in the geotechnical sense with the aim of easier defining the conditions for safe and efficient exploitation of road infrastructure. In the paper is not performed only the characterization of the rock complex at a given time was carried out, as is the case in the previous practice in the world [1-3]. The categorization of the construction of the terrain was carried out on a specific case and a location within the very specific materials of the Durmitor flysch, whereby field geotechnical research and analysis of the existing literature data, provided sufficient material for this approach and categorization of the terrain construction.

The term "Durmitor flysch" was first introduced in geological literature in 1948 by Zarija Bešić [4]. This term implies a powerful geological formation, formed at the turn of the Upper Cretaceous to Palaeogene. It spreads from the North Albanian Plateau and the so-called Cukali zone in the south, across the central part of Montenegro and the northeast Herzegovina all the way to the central Bosnia and Mount Vlašić (Figure 1). It was named after the prominent and spacious development of the southwest slopes of Mount Durmitor, while the best gradation of this formation, as well as all the contemporary geodynamic processes, can be most clearly traced in the area of Čemerno mountain pass in the northeast Herzegovina. The subject of this paper will be precisely the specificities of that part of the Durmitor flysch complex.

Flysch sediments are characterized by complex lithological composition, i.e. they consist of: basal limestone breccias and conglomerates, limestones, siltstones, marly limestones, claystones and marlstones of different thickness and spatial position, which are classified into five superposition packages in this area.

These rock masses are characterized by specific engineering geological properties, which are determined by the specific lithological composition. Therefore, this formation is characterized by heterogeneous and anisotropic geotechnical properties, which depend on predominant lithologic members in the complex, as well as spatial position of the bed packages.
The formation of these sediments is related to the Upper Cretaceous, i.e. the Senonian stage (), and is presented as such on the Basic geological map of SFRY, sheet Gacko [5], while the formation in the region of Montenegro is identified as the Upper Cretaceous-Paleogene $\left(\mathrm{K}_{2}, \mathrm{Pg}\right)$. These lithologic members were deposited in special sedimentary conditions and are therefore found in form of the beds of various thicknesses. The beds of different lithological composition are "packed" in five superposition packages, in which the lithologic members rhythmically and intermittently alternate. The rhythms have different composition as well as spatial spreading, which is a consequence of geological composition of the watershed, climatic conditions that prevailed during the cycle of sedimentation, as well as post-genetic, primarily tectonic conditions that these terrains were exposed to.

The post-genetic tectonic activity caused folding and faulting of these sediments and intensified the process of thrusting of Triassic limestones over the flysch formation, which additionally complicates defining physical-mechanical parameters of these environments and defining engineering geological conditions for construction of both road infrastructure facilities and other construction objects. In this context, the issue of defining stability of the terrain, i.e. the occurrence and type of instabilities is very complex.

Specific climatic conditions that prevailed during the Pleistocene and the Quaternary in the observed area caused formation of numerous glaciers, the melting of which during interglacial periods resulted in extremely intense erosion. Typical glacial forms of relief were formed: cirques, waves, moraines. The activity of the erosional process continued afterwards, so that numerous river valleys were formed: Piva, Tara, Drina, Morača, Neretva, Sutjeska and others, with several levels of fluvioglacial terraces and the accompanying erosional forms of the relief. Sedimentary conditions, tectonic and erosional activities in this region caused, inter alia, formation of various terrain constructions [6]. Terrain construction represents a particular arrangement of natural environments which can be distinguished by various mechanical properties, but in terms of statics act as a whole. The final result of these activities 


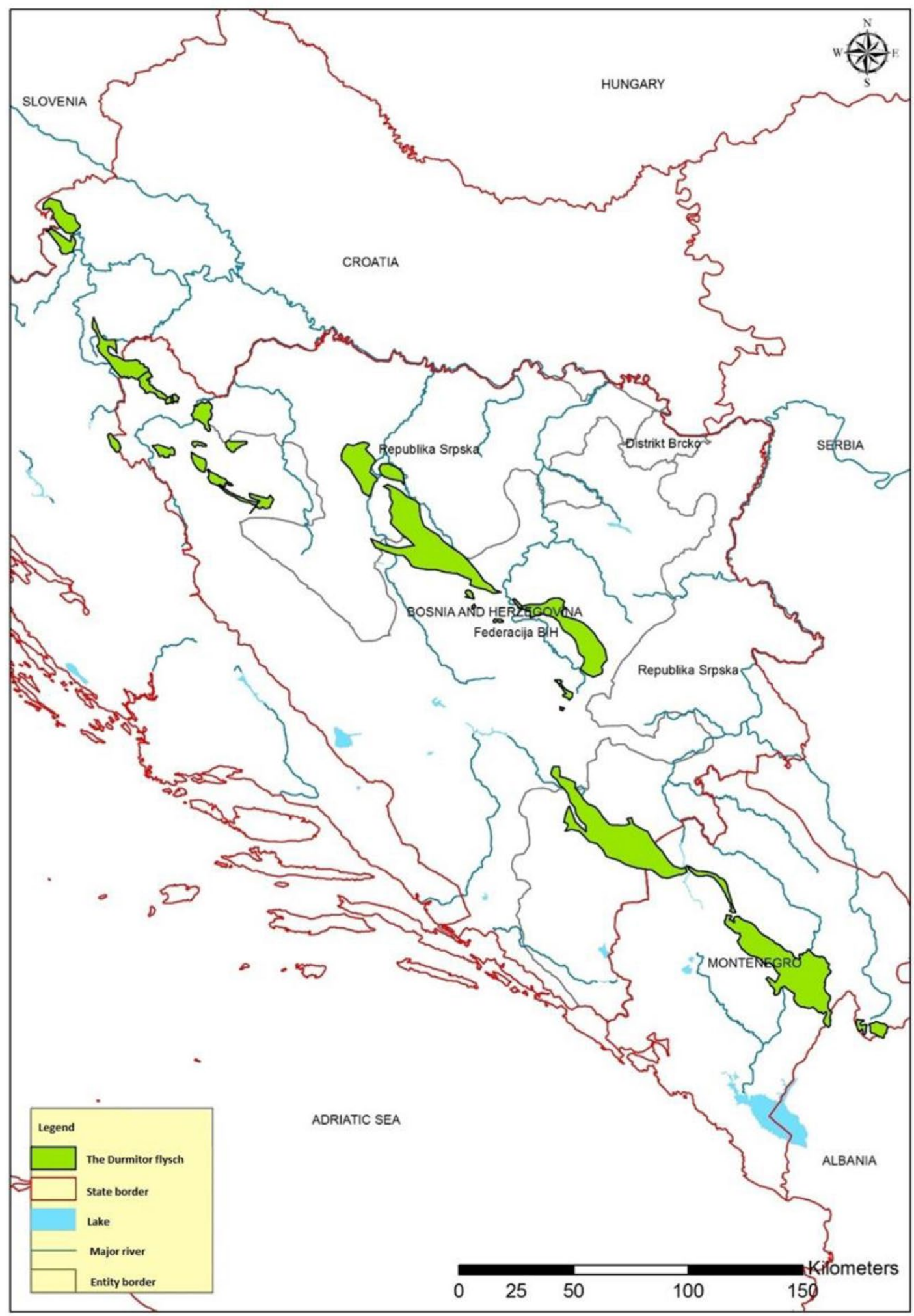

Figure 1: The Durmitor flysch complex spreading. 
also caused the occurrence of various forms of instabilities [7]:

- In the surface areas of the terrain, landslides of the consequent type are predominantly present. The sliding surfaces are generally formed at the contact point of the surface decomposition crust and the bedrock.

- During the periods of intense precipitation (for example, the average annual precipitation in the area of Čemerno is 1650 , and it often exceeds 2000 litre $/ \mathrm{m}^{2}$ ) mudslides are formed, as a specific form of instability in the deluvial slope zone.

- On the valley slopes, primarily depending on spatial position of the beds in the flysch packages, the conditions for formation of landslides are created, with the sliding surfaces predisposed by interlayer surfaces (consequent type of landslides according to Savarenski or lateral spread landslide according to Varnes).

- Instabilities in the form of rockfalls are usually the consequence of technogenic activities (construction of steep slopes during the construction of roads, but they also occur during the exploitation afterwards), while they are considerably less often the result of erosion (geological and natural processes).

In the report, special attention will be paid to the effect of the terrain construction types on the occurrence, types and basic characteristics of the terrain instabilities. This is very important, not only for engineering geological and geotechnical research for the purpose of remediation of instabilities, but also for the purpose of preventive action, i.e. the prevention of occurrence of instabilities during construction of various facilities.

\section{Geological structure of the terrain}

\section{Lithological composition}

The flysch complex was created in the conditions of interconnection of the land system and the presence of sedimentary basin. Namely, the surface streams and erosion of rock masses in the land zone transport the eroded material into the sedimentary basin. The amount and volume (granulometric composition) of the deposits are conditioned by the precipitation regime. This is one of the causes that contributed to the formation of lithologically heterogeneous rock masses and rhythmic alternation of breccias, conglomerates, limestone beds, siltstones, marly limestones, marlstones and claystones. Dimitrijević [8] considers that three facies can be distinguished in the Durmitor flysch complex: carbonate, siliciclastic and mixed facies. The siliciclastic facies is characteristic of the area covered by the sheet Gacko, BGM SFRY. When creating the Basic geological map of SFRY, sheet Gacko, Mirković, Kalezić, Pajović and Vujisić (1980) classified this lithological formation into five superposition packages (sub-stages) within the Upper Cretaceous Senonian Stage $\left(\mathrm{K}_{2}{ }^{3}\right)$ :

1. Basal limestone breccias and conglomerates $\left({ }^{1} \mathrm{~K}_{2}{ }^{3}\right)$ have the largest spread and thickness. Composition of breccias and conglomerates depends on the foundation over which they lie. Most often they are composed of pieces and pebbles of Lower Cretaceous limestone. Diameter of the pieces or fragments of limestone in breccias and conglomerates is up to $0.7 \mathrm{~m}$. The binder is carbonate.

2. Layered breccias and limestones $\left({ }^{2} \mathrm{~K}_{2}^{3}\right)$ are distinguished as the second package, mainly composed of carbonate sediments. Coarsegrained limestone conglomerates and breccias occur in the form of banks thick between 2 and 5 meters. The binder is marly and carbonate. In the geologic column, conglomerates turn into medium-grained, and these turn into fine-grained layered limestone breccias. Breccias are composed of pieces of limestone, chert and marlstone.

3. Breccias, limestones and marlstones $\left({ }^{3} \mathrm{~K}_{2}{ }^{3}\right)$ take up most of the space within this lithological formation. They occur in a wide belt in line with the Dinaric direction of spreading (northwest- southeast). Limestone breccias occur in the form of banks and beds. Their thickness varies from 0.5 to 10 meters. Sandy limestones with a thickness of layers varying from 0.25 to 0.5 meters lie over the breccias. In the geologic column, sandy limestones turn into sandy marlstones, and these turn into greyish-greento brown laminated marlstones. 
4. Sandy-marly flysch series $\left({ }^{4} \mathrm{~K}_{2}^{3}\right)$ is composed of microconglomerates, greywacke, siltstones and marlstones. This superposition package of the Durmitor flysch complex is characterized by very thin layers of individual components that intermittently and repeatedly alternate in the geologic column. They are characterized by prominent folds. The dimensions of the folds range in length from several centimetres (micro) to several hundreds of metres (macro). If the slope is composed of this package, landslides or mudslides are usually formed, i.e. the slopes should be treated as unstable or conditionally stable.

5. Breccias, limestones and marlstones $\left({ }^{5} \mathrm{~K}_{2}{ }^{3}\right)$ represent the fifth and the last package of the Durmitor flysch complex. It is mainly composed of carbonate sediments. Within this package, coarse-grained limestone conglomerates and breccias, limestone breccias, marly limestones and marlstones with chert nodules are present.

Types of instabilities, frequency of their occurrence, their dynamics and volume significantly depend on the slope structure (terrain construction) and these issues will be discussed in the chapter on the terrain constructions (Chapter 3).

\section{Tectonic properties of the terrain}

In the geological past, intense tectonic processes occurred in this area, which was primarily manifested through the process of thrusting of the Middle Triassic massive limestone $\left(\mathrm{T}_{2}{ }^{1}\right)$ over the Durmitor flysch complex [5]. The angle of thrusting in the observed area is $30^{\circ}-35^{\circ}$. The south-southwest side of the Durmitor flysch is erosionallydiscordant.

- Basal breccias and conglomerates $\left({ }^{1} \mathrm{~K}_{2}{ }^{3}\right.$ package 1) are poorly stratified and have a general direction of decline towards the northeast.

- Breccias, limestones and marly limestones $\left({ }^{2} \mathrm{~K}_{2}{ }^{3}\right.$ - package 2$)$ also have a general direction of decline towards the northeast. They are undisturbed, i.e. the folding process is not observed here, while the rupture forms occur as transverse and diagonal decametric faults.
- The package of layered stratified breccias, limestones and marlstones isfolded in numerous metric, decametric and hectometric, upright, inclined and overturned folds with a span from several metres to 500 meters. The folds are upright in one part, while they are inclined in the other part of the package. The axial surfaces are upright and inclined. The vergence is southwest and the vergence angle is up to $10^{\circ}$.

- Within the package of conglomerates, siltstones, marlstones and claystone $\left({ }^{4} \mathrm{~K}_{2}^{3}\right)$ and the package oflayeredbreccias, limestones and marlstones $\left({ }^{5} \mathrm{~K}_{2}^{3}\right)$, numerous metric and decametric, upright and inclined, overturned and recumbent folds developed. Their span ranges from 1 to about 10 metres. The terrain constructed from this package is mostly covered with vegetation and deluvial deposits so its development can be traced in the streambeds and the road cuts [9].

\section{Hydrological and hydrogeological properties of the terrain}

\section{Hydrological properties}

The area constructed from the Durmitor flysch complex in the observed part of the terrain abounds with a very high precipitation, as well as large oscillations in atmospheric temperatureduring the year. The amount of precipitation and temperature oscillations are the most important exogenous agents when it comes to shaping of the relief. Also, these agents significantly affect the occurrence of the terrain instabilities. As an illustration of the previous assertion, Table 1 shows the average precipitation during the year, measured at the rainfall monitoring station Čemerno, expressed in millimetres of deposited water.

Temperature oscillations are enormous both during the year and within a day. The lowest recorded temperature is about $-40^{\circ} \mathrm{C}$, while the highest is about $35^{\circ} \mathrm{C}$. Such temperature range increases the intensity of the surface decomposition, i.e. the mechanical disintegration of the solid rock masses, which is very important in terms of the terrain stability. 
Table 1: Average monthly precipitation at the rainfall monitoring station Čemerno (according to HMIBiH)

\begin{tabular}{cccccccccccccc} 
month & I & II & III & IV & V & VI & VII & VIII & IX & X & XI & XII & total per year \\
\hline \multirow{2}{*}{$\mathrm{mm}$} & 125 & 130 & 160 & 170 & 130 & 100 & 70 & 70 & 125 & 180 & 220 & 170 & 1650 \\
\hline
\end{tabular}

\section{Hydrogeological properties}

In hydrogeological terms, the Quaternary eluvial-deluvial deposits, degraded siltstones, claystones, sandstones and thin laminated marlstones in the periods of abundant precipitation constitute a water-saturated environment. In such conditions, physically bound water reduces the shear strength parameter, adds extra load to the slope and thus contributes to the activation of the sliding process, while the free groundwater in the fracture aggregates of the pores contributes to the physico-chemical decomposition and degradation of the basic rock mass by pressure and circulation [10].

Durmitor flysch sediments are mainly poorly permeable to impermeable rock masses. In the flysch sediments, the groundwater level is in the zone of surface decomposition (eluvial-deluvial part), while it is directly related to the water level in the watercourse in the Quaternary sediments lying over the flysch formation (alluvial planes and river terraces). By the type of porosity, hydrogeological function and the position within the terrain, i.e. by the hydrogeological conditions of formation of the aquifer, the following categories of rock masses can be distinguished in the terrain:

- Hydrogeological collectors with intergranular porosity consist of the Quaternary sediment (Q) including alluvial, proluvial and deluvial deposits.

- Relative hydrogeological collectors consist of basal limestone breccias and conglomerates $\left({ }^{1} \mathrm{~K}_{2}{ }^{3}\right)$, layered breccias and limestones $\left({ }^{2} \mathrm{~K}_{2}{ }^{3}\right)$ and, depending on the spatial position in the relief, they function as a relative hydrogeological collector with fracture porosity. There are no fractures of large dimensions with significant continuity of spreading in these sedimentary packages.

- The rocks with combined fracture-intergranular porosity partly consist of the sediments of the third and the fifth superposition packages $\left({ }^{3} \mathrm{~K}_{2}{ }^{3},{ }^{5} \mathrm{~K}_{2}{ }^{3}\right)$ with breccias and limestones, while the marly component of this package is a classic hydrogeological isolator.

- Hydrogeological isolators, i.e. the impermeable rocks, consist of the fourth superposition package $\left({ }^{4} \mathrm{~K}_{2}^{3}\right)$, within which the marly component is predominant. In contact with water, this component becomes drenched and, depending on its position in the structure, downslope mass movement may occur along the component.

\section{Terrain construction types}

It is known that rock masses, as real bodies in mechanical terms, exhibit very complex behaviour. This is due not only to their specific structure, but also to different states of stress to which they were exposed through the geological history. Therefore, all rock masses, even the youngest, are fragmented into a system of fractures (primary and secondary), which are the result of various stress effects and the dimensions of which exceed the rock masses strength. The terrain constructed from the Durmitor flysch formation has a highly heterogeneous lithological composition, where the lithological components of various physical-mechanical properties, i.e. environments intermittently and rhythmically alternate. Therefore, these are extremely complex terrain constructions, constructed from the following environments [6]:

1. Plastic environments - deluvial clayish debris;

2. Plastic to quasiplastic environments - eluvialdebris andmarly sediments;

3. Quasiplastic environments - sandy-marly flysch series, basal sediment;

4. Brittle environments - limestones, sandstones, greywacke.

Natural terrain constructions in the observed area are shown schematically in Figure 2.

On the basis of the presented terrain construction types in the Durmitor flysch formation, as 

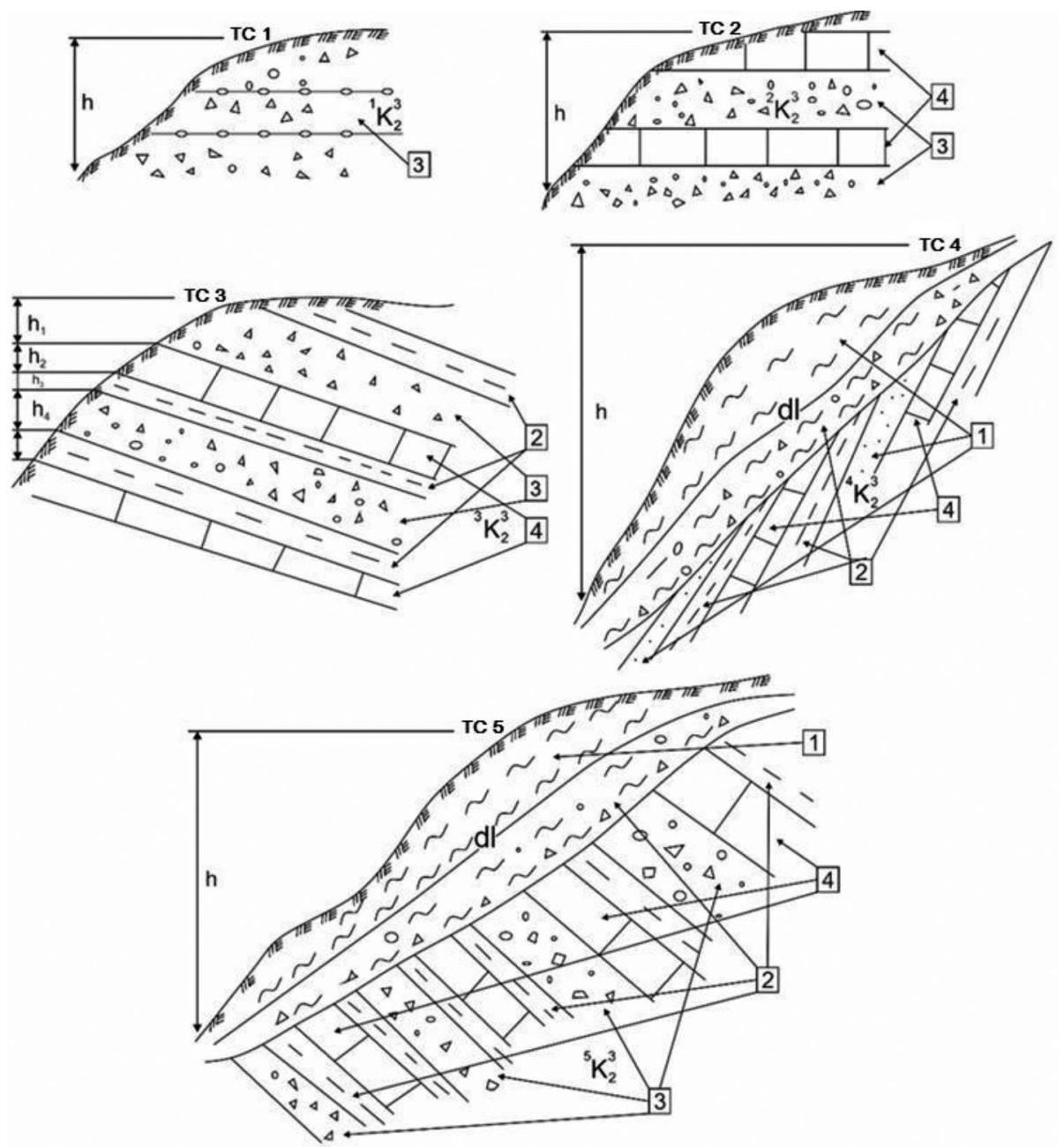

Figure 2: Terrain construction types in the Durmitor flysch complex: 1 - plastic environment; 2 - plastic to quasiplastic environment; 3 -quasiplastic environment; 4 - brittle environment; $h$-construction height; $h_{1} h_{4}$-environment height; TC 1-TC 5 - terrain construction designation.

well as the tectonic relations in the slope, it can be concluded that the forms of deformation are extremely complex. Namely, depending on the spatial position of the geotechnical environments (lithologic members), which intermittently alternate in these packages and have significantly distinct physical-mechanical properties, they behave differently under the influence of particular stresses in the nature.

\section{Contemporary geodynamic processes in the durmitor flysch belt}

General classification of instabilities in our country has been used since 1962 [11]. Accord- ing to this classification, contemporary slope processes are classified into the following:

- rockfalls;

- landslides;

- creeps;

- mudslides.

When it comes to contemporary geodynamic processes in the Durmitor flysch complex, we can say that landslides of various dimensions often occur, commonly in the areas where the fourth and fifth superposition packages $\left({ }^{4} \mathrm{~K}_{2}^{3}\right.$ and $\left.{ }^{5} \mathrm{~K}_{2}{ }^{3}\right)$ are predominant. Rockfalls occur in riverbeds and in the notches and road cuts. Their dimensions are not significant. As for mudslides, geodynamic phenomena in which the mass movement over a sliding surface takes 


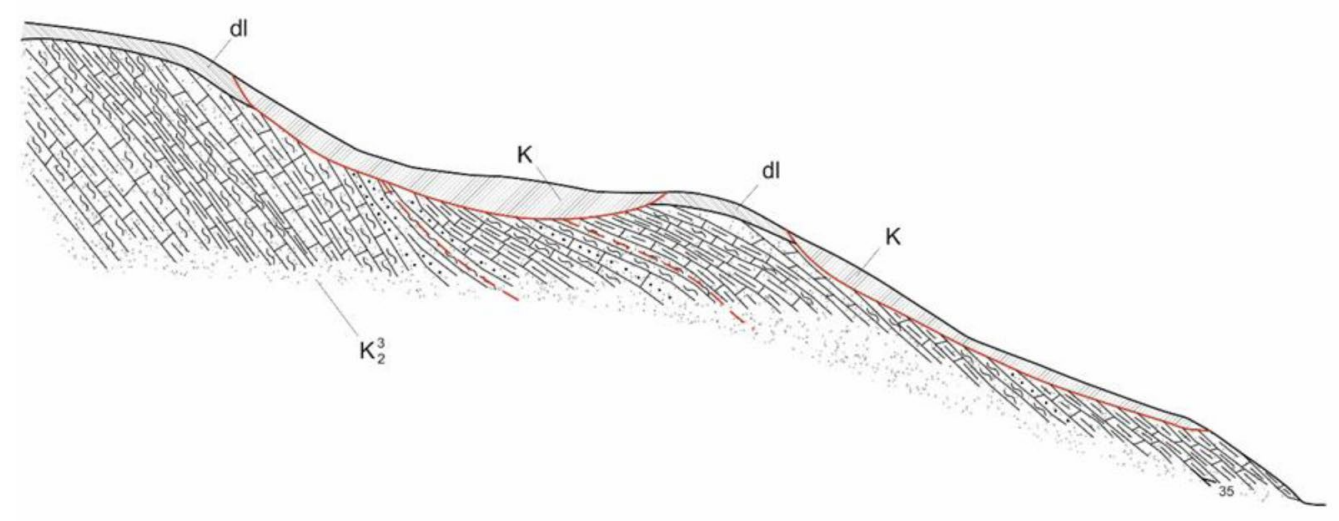

Figure 3: The landslide "Ždralovpotok" is a typical example of a landslide on the Čemerno mountain pass (at the Čemerno tunnel exit portal, main road M 20, section Gacko - Foča, [7]).

place at a very high speed, we can say that they occured on two occasions in the past.

Rockfalls in the area of the Durmitor flysch complex do not have significant spread and large volumes, and are mainly related to steep road cuts, as well as steep valley slopes whose toes are being undercut by the river flows. They occasionally happen due to large temperature differences (the effects of frost), as well as the influence of large amounts of precipitation. The rockfalls with occurrence of massive stone blocks are rare. In general, fragments of centimetric and decimetric dimensions occur, rarely metric. They often happen as a consequence of powerful earthquakes [12].

Screes in the flysch complex area have no significant spread and are mostly located in the area of the overthrustfront, where the massive limestones from the Anisian stage $\left(\mathrm{T}_{2}{ }^{1}\right)$ are thrust over the flysch sediments.

Landslides as contemporary geodynamic processes represent mass movement on the slopes, without detachment from the base, over a clear shear surface (sliding surface). In the area constructed from the Durmitor flysch, especially the northeast side of the Čemerno mountain pass, landslides dominate (Figure 3). Some of them are active, while a number of them are dormant and relict landslides.

Shearing process in active landslides takes place at the contact points of the Cretaceous sediments and the Quaternary formations. In special conditions, in conditions of the complete watersaturation of the terrain and "favourable" position of the bedding surface, the landslide body can also cover the basic rock mass. Sliding takes place over the drenched layers of marlstone and claystone. The most typical example of such landslide is the landslide "ČemernskoOsoje" (Figure 4).

The causes of sliding are multiple and they usually complement each other. In this case, the main cause is the adverse impact of the stream that reduces the erosional base by its erosion activity, thereby removing, i.e. undermining the toes of the slope. In addition to this cause, the slope inclination and water saturation of the rock mass (deluvial deposits, as well as the basic rock mass) have crucial roles in the formation of the landslide. The position of the rock mass structure (the bedding position that is parallel to the slope or lower than the slope inclination) also has an important role. At the time of strong earthquakes, landslides are reactivated and numerous rockfalls occur [12].

Landslides in the observed area predominantly fall into the group of consequent landslides (Zolotarjev, 1983), i.e. the landslides of block structure with the predisposed sliding surfaces. Sliding surfaces are mainly located at the contact point of the eluvial-deluvialdebris and the bedrock, and at the interlayer surfaces that generally decline down the slope. In formation of these landslides, apart from the above-mentioned exogenous agents (water and temperature oscillations), the relief form and the position of the basic rock mass structure also have major roles. Sliding surfaces are usually formed over the layers of claystone and marly claystone. 


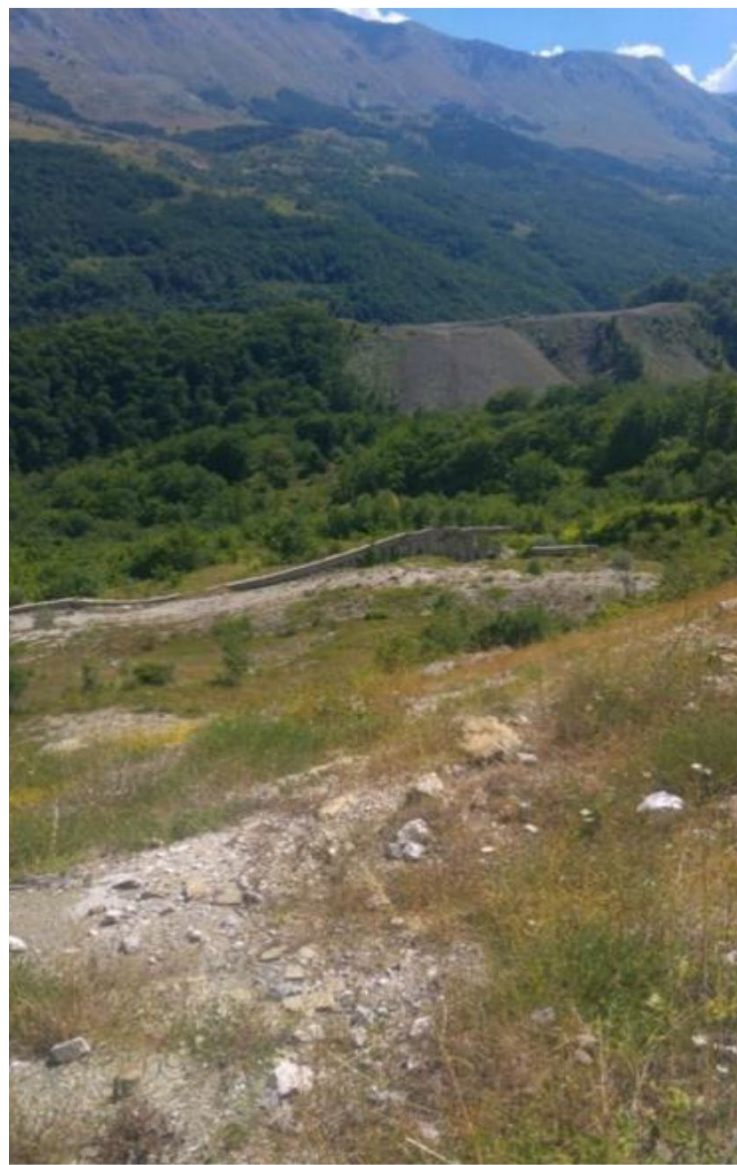

Figure 4: The landslide "ČemernskoOsoje".

Mudslides as geodynamic phenomena represent a distinct group of terrain instabilities, which occur under conditions of the complete watersaturation of the deposit (eluvial-deluvial debris). The speed of the mass movement is quite high and it resembles a torrent. As far as is known, the first such occurrence happened in the fall of 1914 on the northeast slope of Čemerno. On that occasion, a huge amount of rock mass collapsed into the Sutjeska riverbed, dammed the river and temporarily created a lake. The same happened in November 2005 near Mojkovac in Montenegro, when a huge amount of rock mass tumbled into the Tara riverbed.

\section{Discussion}

The Durmitor flysch complex represents a specific lithological formation, formed during the
Upper Cretaceous Senonian Stage $\left(\mathrm{K}_{2}^{3}\right)$. This lithological formation consists of five superposition bed packages, which are mutually substantially different in their lithological, hydrogeological and geotechnical properties [13]. Dimitrijević considers that three facies can be distinguished in the Durmitor flysch complex: carbonate, siliciclastic and mixed facies. This paper clearly distinguishes five packages within the Durmitor flysch.

For the first time in geological literature, this paper distinguishes five types of terrain construction. Terrain construction represents a particular arrangement of natural environments which can be distinguished by various mechanical properties, but in terms of statics act as a whole.

Contemporary geodynamic processes, as defined bygeneral classification [8] are present in this formation in all their forms, to a greater or lesser extent.

Particular emphasis is put on landslides, where in conditions of "favorable" position of the bedding surfaces a sliding plane is formed over them (the marly component). The landslides mostly have a block structure, they are formedover the predisposed surfaces and fall into the group of consequent landslides.

\section{Conclusion}

The Durmitor flysch complex represents a complex lithological formation, mainly formed during the Upper Cretaceous Senonian Stage $\left(\mathrm{K}_{2}^{3}\right)$, while the authors ofthe Basic geological map of SFRY classified this lithological formation in the region of Montenegro as the formation from the transitional period between the Upper Cretaceous and the Paleogene (K,Pg).

On the territory of Bosnia and Herzegovina, this lithological formation is represented with five superposition packages, which differ both in lithological composition and in thickness of the layers, as well as their rhythmicity.

The Durmitor flysch complex consists of the layers of basal limestone breccias and conglomerates, limestone and siltstone, marly limestone, marlstone and sporadic claystone. These rock masses are characterized by specific engineering geological properties, which are 
conditioned by the heterogeneous lithological composition. Therefore, this complex is characterized by heterogeneous and anisotropic geotechnical properties, which depend on the predominant lithologic members in the complex, as well as spatial position of the superposition bed packages.

Lithological heterogeneity also influenced the heterogeneity of physical-mechanical properties and the behaviour of such environments under the influence of static and dynamic loads, i.e. in case of disturbance of primary geostatic conditions in the terrain.

The lithologic members were deposited in special sedimentary conditions and are therefore found in form of the beds of various thicknesses. They compose characteristic bed packages, which intermittently and rhythmically alternate.

Post-genetic tectonic activity caused folding and faulting of these sediments, which additionally complicates defining of physical-mechanical parameters of these environments and defining of geotechnical conditions for construction of various types of objects in this terrain.

Specific climatic conditions characterized by high precipitation, as well as large temperature oscillations, both within a day and during the year, caused the formation ofnumerous river valleys and other erosional valleys.As a result of these activities, inter alia, various terrain constructionswere formed and various types of instabilities occurred.

In the surface areas of the terrain, landslides of the consequent type are predominantly present. The sliding surfaces are generally formed at the contact point of the surface decomposition crust and the bedrock. Due to the fact that these landslides are practically moving and their activity is particularly manifested after intense precipitation and sudden snowmelt, problems with exploitation of the roads and other construction objects built on these terrains are evident.

On the valley slopes, primarily depending on spatial position of the beds in the flysch packages, the conditions for formation of landslides are created, with the sliding surfaces predisposed by interlayer surfaces.
The occurrence of instabilities of the rockfall type is less frequent.

Mudslides,as contemporary geodynamic phenomena with huge amounts of material tumbling into the riverbeds or erosional bases at a high speed, have been recorded on two occasions over the past 100 years.

\section{References}

[1] Jia-wen, Z., Chong, S., Fu-gang, X. (2013): Geotechnical Characteristics and Stability Analysis of RockSoil Aggregate Slope at the Gushui Hydropower Station, Southwest China. The Scientific World Journal, 540636, 16 p.

[2] Safaei, M., Omar, H., Yousof, Z.B.M., Motevalli, A. (2013): Application of a Physically based Model for Terrain Stability Mapping in North of Iran. Global Journals Inc. (USA), 13(2).

[3] Tofani, V., Bicocchi, G., Rossi, G., Segoni, S., D’Ambrosio, M., Casagli, N., Catani, F. (2017): Soil characterization for shallow landslides modeling: a case study in the Northern Apennines (Central Italy). Landslides, 14(2), pp. 755-770.

[4] Bešić, Z. (1948): Geotectonic structure of northern Montenegro, Bulletin of the Natural Science Museum of Serbian Land, ser. A-1, Belgrade.

[5] Mirković, M., Kalezić, M., Pajović, M., Vujisić, P. (1980): BGM SFRY, Explanatory booklet for the sheet Gacko, Federal Geological Institute of SFRY, Belgrade.

[6] Perić J., Šutić J., Božinović D. (1967): Terrain constructions as the basis for research on the terrain stability, Advice on the issues of landslides in the road construction, JDP, Belgrade.

[7] Lokin, P., Lapčević, R. (2000): Project implementation plan, Book 1, Geotechnical investigations and geotechnical conditions, Main road M 20 Gacko - Foča, section Vrba - Trnovaluka, Makspro Ltd., Belgrade.

[8] Dimitrijević, M. (1995): Geology of Yugoslavia, Geological Institute: Belgrade.

[9] Golijanin, A.: The impact of engineering geological properties of the Durmitor flysch on geotechnical conditions for construction, doctoral dissertation (in the making).

[10] Sunarić, D. (2017): Engineering geodynamics, Theory and practice, Academy of Engineering Sciences of Serbia and the Water Management Institute, "Jaroslav Černi“, Belgrade.

[11] Janjić, M. (1962): Engineering geological characteristics of the terrain of PR Serbia, Belgrade. 
[12] Sunarić, D., Stojinić, N., Nedeljković, S. (2008): Seismicity of the terrain and exogenous geodynamic phenomena (landslides and rockfalls) in western Serbia. The Water Management Institute, "Jaroslav Černi", Belgrade.

[13] Jevremović, D. (2015): Methods of engineering geological research. University of Belgrade - Faculty of Mining and Geology: Belgrade. 